\title{
Association between endothelin-1/endothelin receptor A and inflammation in mouse kidneys following acute ischemia/reperfusion
}

\author{
$\mathrm{JIE} \mathrm{NIU}^{1 *}, \mathrm{JUNFANG} \mathrm{WU}^{1 *}$, XIAOPENG $\mathrm{LI}^{2}$ and FENXI ZHANG ${ }^{3}$ \\ ${ }^{1}$ Morphology Laboratory of Xinxiang Medical University; ${ }^{2}$ Department of Ophthalmology, \\ The Third Affiliated Hospital of Xinxiang Medical University; ${ }^{3}$ Department of Anatomy, \\ Sanquan College, Xinxiang Medical University, Xinxiang, Henan 453003, P.R. China
}

Received February 19, 2014; Accepted December 3, 2014

DOI: $10.3892 / \mathrm{mmr} .2014 .3138$

\begin{abstract}
Renal ischemia/reperfusion (I/R) is a common risk factor for renal failure. Expression of endothelin-1 (ET-1) and its receptor $\mathrm{ET}_{\mathrm{A}}$ were also reported to be involved in the development of acute and chronic renal disease. The present study was designed to investigate the association between inflammation and ET-1/ET $\mathrm{A}_{\mathrm{A}}$ expression in mouse kidneys following acute $I / R$. The results demonstrated that acute renal I/R caused a significant increase in ET-1 and $\mathrm{ET}_{\mathrm{A}}$ gene and transcriptional levels compared with those of the sham group $(\mathrm{P}<0.01)$. Ischemia alone also resulted in a marked increase of ET-1 and $\mathrm{ET}_{\mathrm{A}}$ expression compared with that of the sham group $(\mathrm{P}<0.05)$. In addition, $\mathrm{ET}-1$ and $\mathrm{ET}_{\mathrm{A}}$ expression was significantly increased in the I/R group compared with that of the ischemia group $(\mathrm{P}<0.05$ or $\mathrm{P}<0.01)$. Of note, the altered expression levels of inflammatory cytokines tumor necrosis factor (TNF)- $\alpha$ and interleukin (IL)- 6 in kidneys following $\mathrm{I} / \mathrm{R}$ and ischemia alone were correlated with the expression of ET-1 and ET $_{\mathrm{A}}$. Hypoxia is the most important stimulus of I/R for tissue injury. In kidneys, ET-1 is primarily produced by renal glomerular endothelial cells (RGECs). In the present study, treatment with hypoxia alone or hypoxia/reoxygenation were found to increase ET-1 and $\mathrm{ET}_{\mathrm{A}}$ expression in human RGECs $(\mathrm{P}<0.05$ or $\mathrm{P}<0.01)$. In order to elucidate the role of inflammation in the ischemia- and hypoxia-induced upregulation of ET-1 and $\mathrm{ET}_{\mathrm{A}}$, human RGECs were exposed to different concentrations of TNF- $\alpha$. As expected, TNF- $\alpha$ increased ET-1 and $\mathrm{ET}_{\mathrm{A}}$ expression in a dose-dependent manner; furthermore, application of the TNF- $\alpha$ inhibitor CAY10500 partially
\end{abstract}

Correspondence to: Professor Fenxi Zhang, Department of Anatomy, Sanquan College, Xinxiang Medical University, 601 Jinshiu Road, Xinxiang, Henan 453003, P.R. China

E-mail: fxzhang0824@gmail.com

${ }^{*}$ Contributed equally

Key words: endothelin-1, endothelin receptor A, inflammation, ischemia/reperfusion, hypoxia/reoxygenation, kidneys inhibited hypoxia-induced ET-1 and $\mathrm{ET}_{\mathrm{A}}$ expression. In conclusion, these results indicated that $\mathrm{I} / \mathrm{R}$ induced upregulation of ET-1 and $\mathrm{ET}_{\mathrm{A}}$ in the kidneys, which was, at least in part, dependent on the production of inflammatory cytokines.

\section{Introduction}

Renal ischemia/reperfusion ( $\mathrm{I} / \mathrm{R})$ is a common risk factor for acute renal failure (1). Inflammatory responses were also reported to be partially responsible for renal damage following I/R injury. Previous studies have demonstrated that acute renal I/R injury may initiate the inflammatory cascade; in addition, the inhibition of inflammation was demonstrated to protect kidneys against I/R injury (2,3).

Endothelin-1 (ET-1) is a protein primarily produced by endothelial cells (4); in the kidneys, ET-1 is produced by renal glomerular endothelial cells (RGECs), in which it is predominantly located within the cytoplasm (5). However, in nephrotic states, ET-1 may be produced by and localized in other cells, such as tubular epithelial cells (5). ET-1 production contributes to vascular tone and other cellular processes via activation of its receptors, which include type $A\left(E T_{A}\right)$ and type $\mathrm{B}\left(\mathrm{ET}_{\mathrm{B}}\right)$ (4). Previous studies have shown that ET-1 production in kidneys was increased with the development of chronic renal diseases (6), and the increase of ET-1 was also found to inversely accelerate the progress of chronic renal diseases (7). In addition, the infusion of exogenous ET-1 was reported to lead to functional and morphological alterations of rat kidneys (7).

$\mathrm{ET}_{\mathrm{A}}$, a $\mathrm{G}$ protein-coupled receptor, is one of the primary receptors of ET-1. In the majority of cases, $\mathrm{ET}_{\mathrm{A}}$ and $\mathrm{ET}_{\mathrm{B}}$ have opposing actions (8); however, upregulation of both receptors has been observed in chronic renal diseases (9). Selective inhibition of $\mathrm{ET}_{\mathrm{A}}$ using its antagonists, such as atrasentan, was demonstrated to have beneficial effects on renal injury progression (10). Previous studies have shown that ET-1 was upregulated in rat kidneys following chronic I/R $(11,12)$; however, the underlying mechanisms of action of this remain to be elucidated. In the present study, the expression of ET-1 and $\mathrm{ET}_{\mathrm{A}}$ in mouse kidneys and human renal glomerular endothelial cells (HRGECs) was investigated following acute 
Table I. Primers for reverse transcription quantitative polymerase chain reaction.

A, Mouse primers

\begin{tabular}{|c|c|c|c|}
\hline Primers & Sense & Sequence & Product size (bp) \\
\hline ET-1 & $\begin{array}{l}\text { Sense } \\
\text { Antisense }\end{array}$ & $\begin{array}{l}\text { ggtggaaggaaggaaactac } \\
\text { caagaagaggcagaaaggca }\end{array}$ & 367 \\
\hline $\mathrm{ET}_{\mathrm{A}}$ & $\begin{array}{l}\text { Sense } \\
\text { Antisense }\end{array}$ & $\begin{array}{l}\text { aacaagtgtatgaggacggc } \\
\text { ggccaagatgaaggaaagaa }\end{array}$ & 325 \\
\hline TNF- $\alpha$ & $\begin{array}{l}\text { Sense } \\
\text { Antisense }\end{array}$ & $\begin{array}{l}\text { ccgatgggttgtaccttgtc } \\
\text { gggctgggtagagagaatggat }\end{array}$ & 352 \\
\hline IL-6 & $\begin{array}{l}\text { Sense } \\
\text { Antisense }\end{array}$ & $\begin{array}{l}\text { gatgctaccaaactggatataatc } \\
\text { ggtccttagccactccttctgtg }\end{array}$ & 269 \\
\hline$\beta$-actin & $\begin{array}{l}\text { Sense } \\
\text { Antisense }\end{array}$ & $\begin{array}{l}\text { ttctttgcagctccttcgttgccg } \\
\text { tggatggetacgtacatggctggg }\end{array}$ & 458 \\
\hline
\end{tabular}

B, Human primers

\begin{tabular}{|c|c|c|c|}
\hline Primers & Sense & Sequence & Product size (bp) \\
\hline ET-1 & $\begin{array}{l}\text { Sense } \\
\text { Antisense }\end{array}$ & $\begin{array}{l}\text { catcatttgggtcaacactcc } \\
\text { cttcctctcactaactgctg }\end{array}$ & 281 \\
\hline $\mathrm{ET}_{\mathrm{A}}$ & $\begin{array}{l}\text { Sense } \\
\text { Antisense }\end{array}$ & $\begin{array}{l}\text { ctcggtactcccataatcct } \\
\text { gaacattcaccagaactgcc }\end{array}$ & 332 \\
\hline TNF- $\alpha$ & $\begin{array}{l}\text { Sense } \\
\text { Antisense }\end{array}$ & $\begin{array}{l}\text { gagtgacaagcetgtagccca } \\
\text { gcaatgatcccaaagtagacc }\end{array}$ & 437 \\
\hline IL-6 & $\begin{array}{l}\text { Sense } \\
\text { Antisense }\end{array}$ & $\begin{array}{l}\text { gtagtgaggaacaagccaga } \\
\text { gagagccaaccaaccaaaca }\end{array}$ & 245 \\
\hline GADPH & $\begin{array}{l}\text { Sense } \\
\text { Antisense }\end{array}$ & $\begin{array}{l}\text { gggtgtgaaccatgagaagt } \\
\text { gtagaggcagggatgatgtt }\end{array}$ & 225 \\
\hline
\end{tabular}

ET-1, endothelin 1; $\mathrm{ET}_{\mathrm{A}}$, ET-1 receptor, type A; TNF- $\alpha$, tumor necrosis factor $\alpha$; IL-6, interleukin 6.

renal I/R and hypoxia/reoxygenation $(\mathrm{H} / \mathrm{R})$; in addition, the associations between inflammation and $\mathrm{ET}-1 / \mathrm{ET}_{\mathrm{A}}$ expression were examined.

\section{Materials and methods}

Animal preparation. A total of 18 male C57BL/6 mice (eight-week-old; weight, $23 \pm 0.6 \mathrm{~g}$ ) were obtained from the Animal Center of Xinxiang Medical University (Henan, China) and randomly divided into three groups: Sham ischemia, ischemia and ischemia/reperfusion. The mice were housed in a temperature-controlled room $\left(22-24^{\circ} \mathrm{C}\right)$ under a 12-h light/dark cycle, with access to standard mouse chow and water. Animals were anesthetized by intraperitoneal injection of sodium pentobarbital $(60 \mathrm{mg} / \mathrm{kg}$; Beijing Propbs Biotechnology Co., Ltd, Beijing, China) and maintained on a $37.5^{\circ} \mathrm{C}$ Homeothermic Blanket for Rodents (Shanghai Youer Equipment Scientific Co., Ltd, Shanghai, China). Kidneys and renal arteries were exposed following abdominal incisions. Renal arteries in the ischemia group were closed using bulldog clamps (Dongxiyi Science and Technology Co. Ltd, Beijing,
China) for $1 \mathrm{~h}$; mice were then sacrificed by cervical dislocations under anesthesia (60 mg/kg sodium pentobartital), and plasma and kidneys were collected and frozen at $-80^{\circ} \mathrm{C}$ until further use. Renal arteries in the I/R group were temporarily closed using bulldog clamps for $1 \mathrm{~h}$ and subsequently reopened by removal of the bulldog clamps to allow for reperfusion for $1 \mathrm{~h}$; mice were then sacrificed, and plasma and kidneys were collected. Mice in the sham ischemia group received a sham surgery, without closing the renal arteries. The use of animals and study protocols of the present study were approved by the Ethics Committee of Xinxiang Medical University (Xinxiang, China).

Culture of human RGECs (HRGECs). HRGECs were purchased from ScienCell Research Laboratories (Carlsbad, CA, USA) and cultured in special Endothelial Cell Medium (ScienCell Research Laboratories). HRGECs were exposed to hypoxia for $3 \mathrm{~h}$ using a hypoxia C-chamber (Biospherix, Ltd, Lacona, NY, USA) and then placed in a cell incubator for $1 \mathrm{~h}$ for reoxygenation; the mRNA and protein expression levels of tumor necrosis factor (TNF)- $\alpha$ and interleukin (IL)-6 were 
A

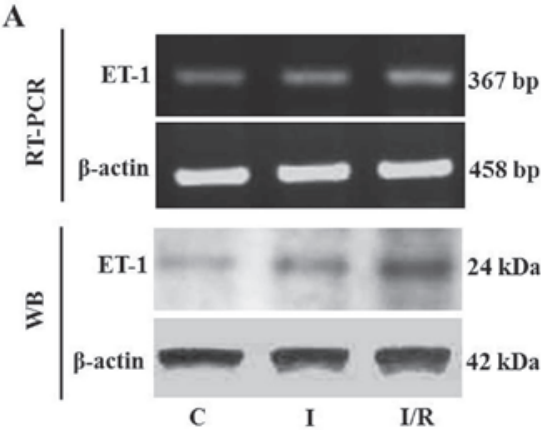

B

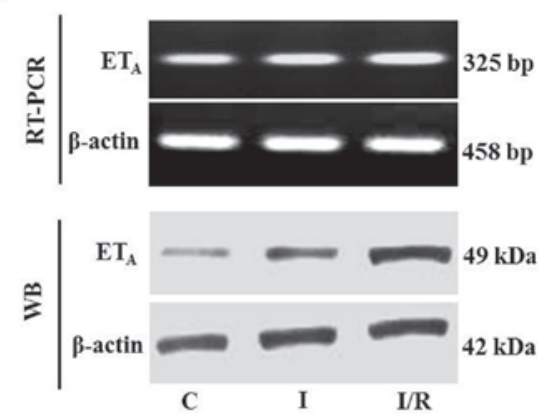

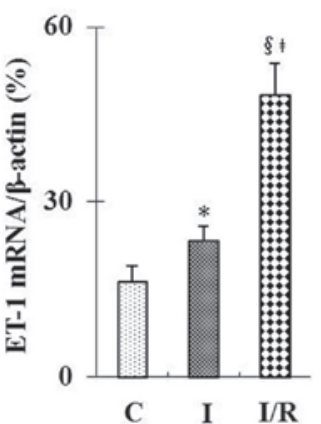
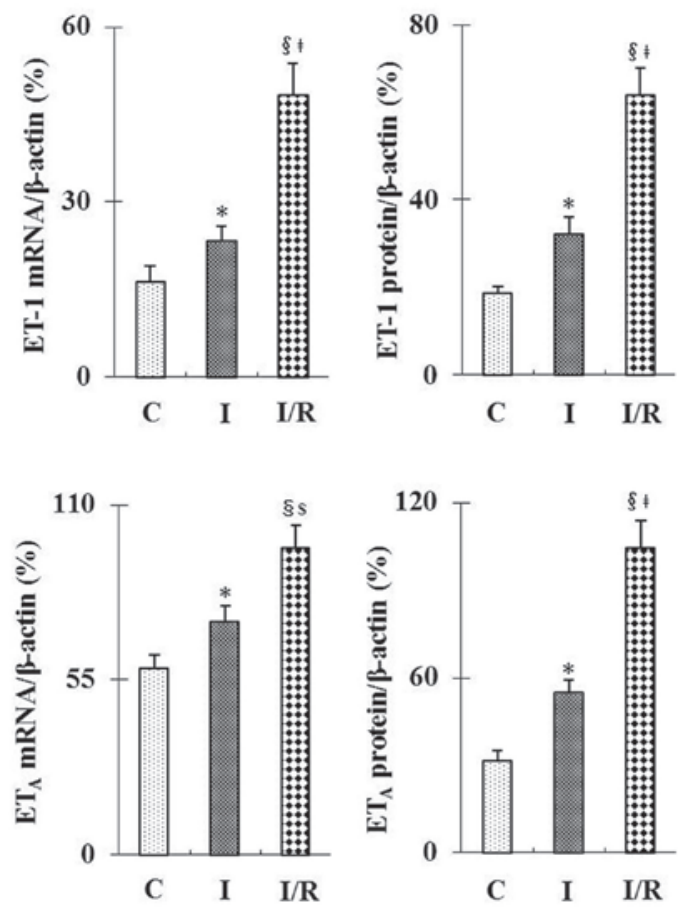

Figure 1. ET-1 and $\mathrm{ET}_{\mathrm{A}}$ expression in mouse kidneys following ischemia and I/R. RT-qPCR and WB analysis of (A) ET-1 and (B) ET $\mathrm{mRNA}$ and protein expression levels following ischemia and I/R. Values are presented as the mean \pm standard deviation $(\mathrm{n}=6 / \mathrm{group})$. ${ }^{*} \mathrm{P}<0.05$ or ${ }^{\S} \mathrm{P}<0.01 \mathrm{vs}$. $\mathrm{C}$; ${ }^{\$} \mathrm{P}<0.05$ or ${ }^{\dagger} \mathrm{P}<0.01$ vs. I. ET-1, endothelin 1; ET ${ }_{\mathrm{A}}$, ET-1 receptor, type A; RT-qPCR, reverse transcription quantitative polymerase chain reaction; WB, western blot; C, sham ischemia group; I, ischemia only group; I/R, ischemia/reperfusion group.

then measured using reverse transcription quantitative polymerase chain reaction (RT-qPCR) and western blot analyses. In order to elucidate the effect of inflammation on ET-1 and $\mathrm{ET}_{\mathrm{A}}$ production, HRGECs were exposed to $0,1,5,10$ and $50 \mathrm{U} / \mathrm{ml}$ TNF- $\alpha$ (Sigma-Aldrich, Shanghai, China) for $6 \mathrm{~h}$; ET-1 and $\mathrm{ET}_{\mathrm{A}}$ expression levels were then measured using RT-PCR and western blot. In parallel, another group of HRGECs were incubated with the TNF- $\alpha$ inhibitor CAY10500 (5 $\mu \mathrm{M}$; Sigma-Aldrich) $30 \mathrm{~min}$ prior to and during hypoxic treatments.

ELISA. Protein levels of TNF- $\alpha$ and IL-6 in mouse plasma following the induction of ischemia and ischemia/reperfusion were measured using a mouse TNF- $\alpha$ Quantikine ELISA kit (R\&D Systems Inc., Minneapolis, MN, USA) and a mouse IL-6 Quantikine ELISA kit (R\&D Systems Inc.), according to the manufacturer's instructions. Absorbance was measured at $450 \mathrm{~nm}$ using an $\mathrm{xMark}^{\mathrm{TM}}$ microplate reader (Bio-Rad Laboratories, Inc., Hercules, CA, USA).

$R T$ - $q P C R$. Total RNA was extracted from the frozen kidneys and HRGECs using RNeasy Mini kits (Invitrogen Life Technologies, Carlsbad, CA, USA) and complementary (c)DNA was synthesized using a SuperScript II 1st Strand DNA Synthesis kit (Invitrogen Life Technologies) according to the manufacturer's instructions. qPCR reactions were performed using 2X PCR reaction solution (Sigma-Aldrich, St. Louis, MO, USA) with $100 \mathrm{ng}$ cDNA and $0.3 \mu \mathrm{M}$ primers. The primers used for PCR reactions are listed in Table I.

Western blot analysis. Proteins were extracted from the frozen kidneys and HRGECs, and separated using
12\% SDS-PAGE (Zhengzhou Bao-Biotechnology Co., Ltd, Zhengzhou, China). Following electrophoresis, proteins were transferred onto polyvinylidene fluoride membranes (Zhengzhou Jiuh-Bao-Biotechnology Co.,Ltd). The membranes were blocked with 5\% non-fat milk (Zhengzhou Jiuh-Bao-Biotechnology Co., Ltd) in Tris-buffered saline with Tween-20 (TBS-T; Beijing Solarbio Science and Technology Co., Ltd, Beijing, China) and then incubated with the following primary antibodies: goat immunoglobulin ( $\mathrm{IgG}$ ) polyclonal anti-ET-1 (1:500; Santa Cruz Biotechnology Inc., Dallas, TX, USA), rabbit IgG polyclonal anti-ET $\mathrm{A}(1: 1,000$; Thermo Fisher Scientific Inc., Waltham, MA, USA), goat IgG polyclonal anti-TNF- $\alpha$ (1:1,000; Santa Cruz Biotechnology Inc.), goat IgG polyclonal anti-IL-6 (1:500, Santa Cruz Biotechnology Inc.) and mouse $\operatorname{IgG}$ monoclonal anti- $\beta$-actin (1:2,000; Santa Cruz Biotechnology Inc.) at $4^{\circ} \mathrm{C}$ overnight. Subsequently, the membranes were washed three times with TBS-T and incubated with donkey anti-goat IgG, donkey anti-rabbit IgG or donkey anti-mouse IgG horseradish peroxidase-conjugated secondary antibodies (1:10,000; Santa Cruz Biotechnology Inc.) for $1 \mathrm{~h}$ at room temperature. Immunoreactive bands were visualized using an Enhanced Chemiluminescence Western Blotting Substrate kit (Thermo Fisher Scientific Inc.).

Statistical analysis. Statistical analysis was performed using SPSS 11.5 software (SPSS Inc., Chicago, IL, USA). Values are presented as the mean \pm standard deviation. Univariate comparisons of the means were evaluated using one-way analysis of variance with Tukey's post-hoc adjustment for multiple comparisons. $\mathrm{P}<0.05$ was considered to indicate a statistically significant difference between values. 

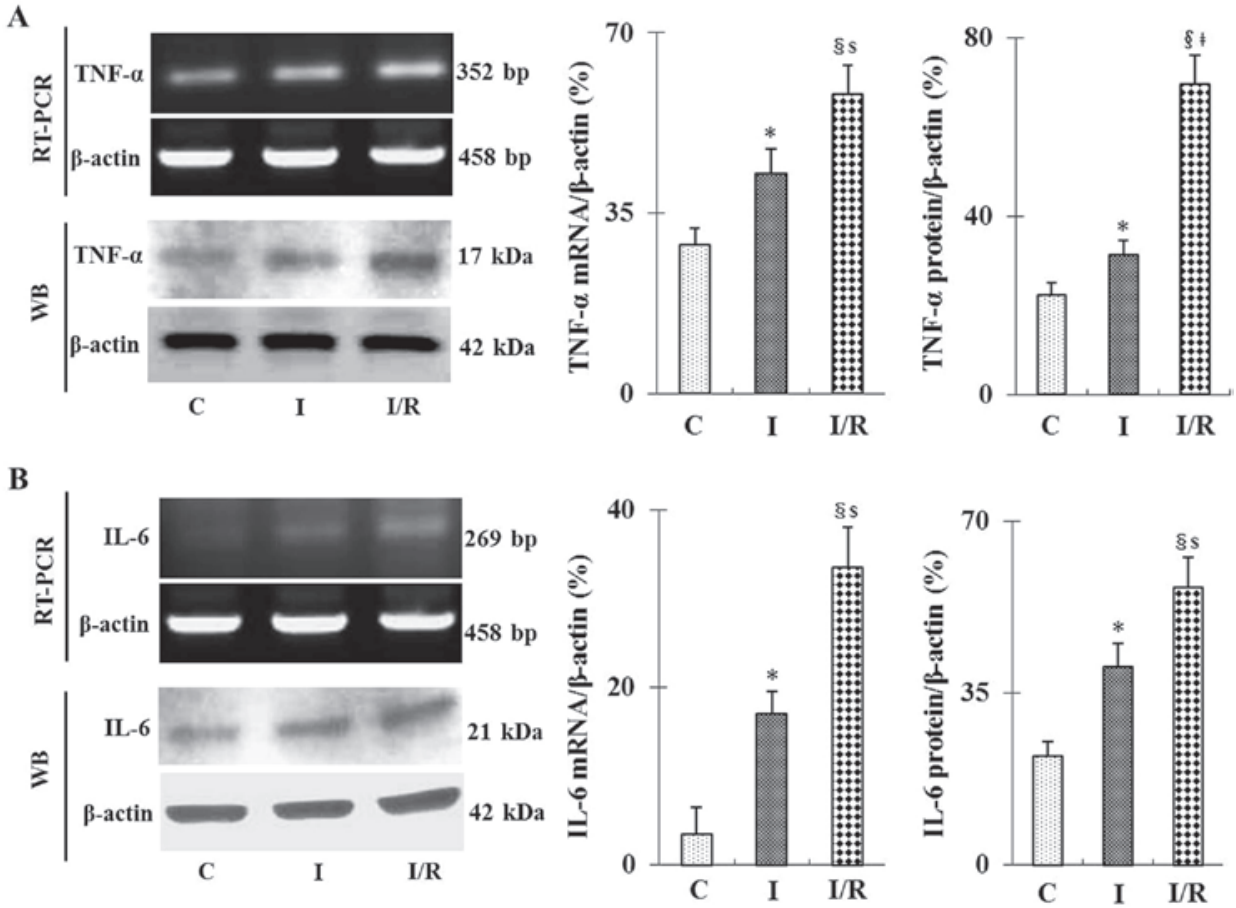

Figure 2. TNF- $\alpha$ and IL-6 expression levels in mouse kidneys following ischemia and I/R. RT-qPCR and WB analysis of (A) TNF- $\alpha$ and (B) IL-6 mRNA and protein expression. Values are presented as the mean \pm standard deviation ( $\mathrm{n}=6 /$ group). ${ }^{*} \mathrm{P}<0.05$ or ${ }^{\S} \mathrm{P}<0.01$ vs. $\mathrm{C} ;{ }^{\$} \mathrm{P}<0.05$ or ${ }^{\ddagger} \mathrm{P}<0.01 \mathrm{vs}$. I. TNF- $\alpha$, tumor necrosis factor $\alpha$; IL-6, interleukin 6; RT-qPCR, reverse transcription quantitative polymerase chain reaction; WB, western blot; C, sham ischemia group; I, ischemia only group; $\mathrm{I} / \mathrm{R}$, ischemia/reperfusion group.
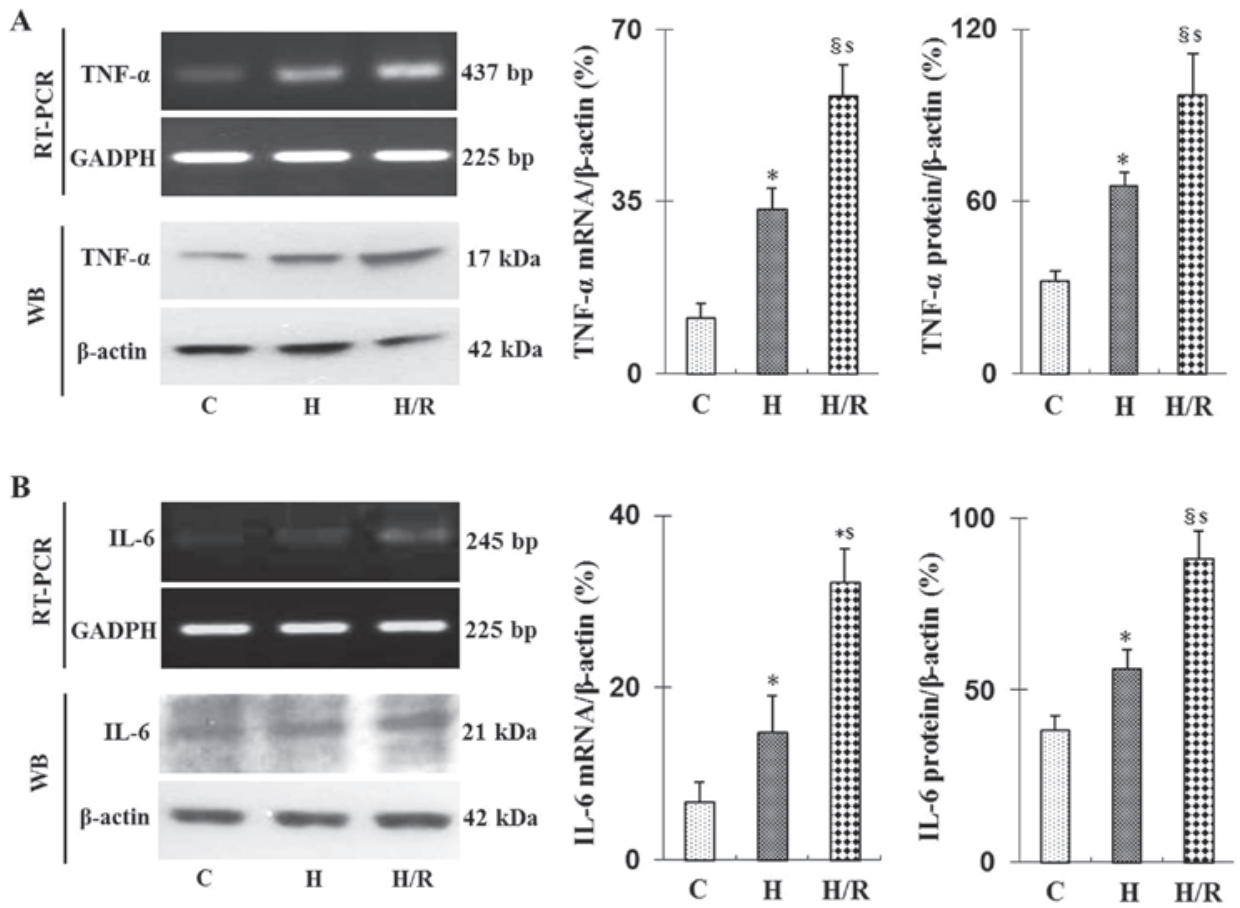

Figure 3. TNF- $\alpha$ and IL-6 expression in HRGECs following exposure to hypoxia and H/R. (A) RT-qPCR and WB analysis of (A) TNF- $\alpha$ and (B) IL-6 mRNA and protein expression in HRGECs following exposure to hypoxia and H/R. Values are presented as the mean \pm standard deviation $(n=4 / g r o u p)$. ${ }^{*} \mathrm{P}<0.05$ or ${ }^{\$} \mathrm{P}<0.01$ vs. C; ${ }^{\$} \mathrm{P}<0.05$ vs. I. TNF- $\alpha$, tumor necrosis factor $\alpha$; IL-6, interleukin 6; RT-qPCR, reverse transcription quantitative polymerase chain reaction; WB, western blot; $\mathrm{C}$, sham hypoxia group; I, hypoxia only group; H/R, hypoxia/reoxygenation group; HRGECs, human renal glomerular endothelial cells.

\section{Results}

$I / R$ increases $m R N A$ and protein expression levels of ET-1 and $E T_{A}$ in mouse kidneys. As shown in Fig. 1A and B, RT-PCR and western blot analyses revealed that I/R significantly increased the mRNA and protein expression levels of ET-1 and $\mathrm{ET}_{\mathrm{A}}$ compared with those of the sham group $(\mathrm{P}<0.01)$. Following ischemia only, a moderate but significant increase 

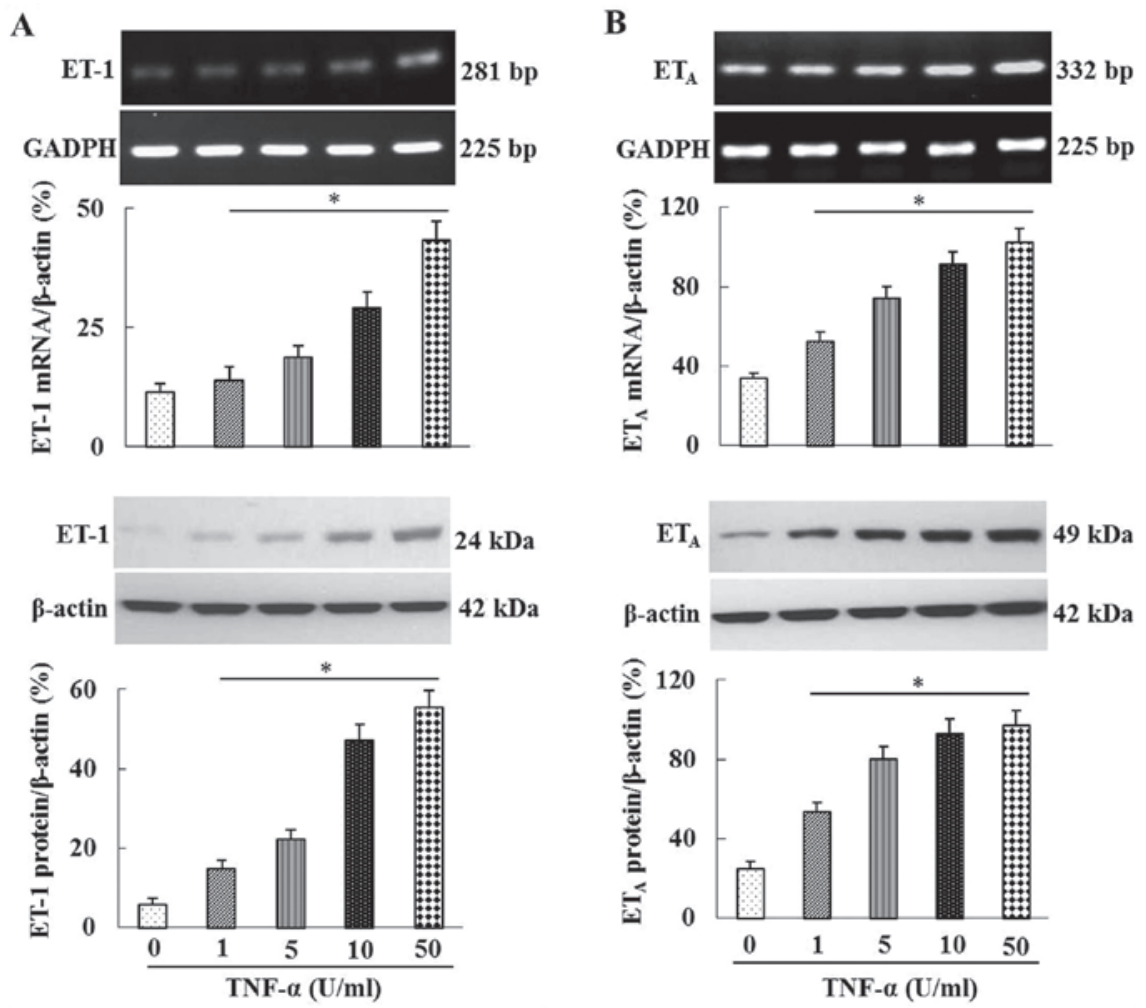

Figure 4. TNF- $\alpha$ induces ET-1 and $\mathrm{ET}_{\mathrm{A}}$ expression in HRGECs. Reverse transcription quantitative polymerase chain reaction and western blot analysis of (A) ET-1 and (B) ET $\mathrm{ARNA}$ and protein expression levels in HRGECs following exposure to 0,1,5 10 and $50 \mathrm{U} / \mathrm{ml} \mathrm{TNF}-\alpha$. Values are presented as the mean \pm standard deviation ( $\mathrm{n}=4$ /group). ${ }^{*} \mathrm{P}<0.05$ vs. $0 \mathrm{U} / \mathrm{ml} \mathrm{TNF}-\alpha$. TNF- $\alpha$, tumor necrosis factor $\alpha$; ET-1, endothelin 1; ETA, ET-1 receptor, type A; HRGECs, human renal glomerular endothelial cells.
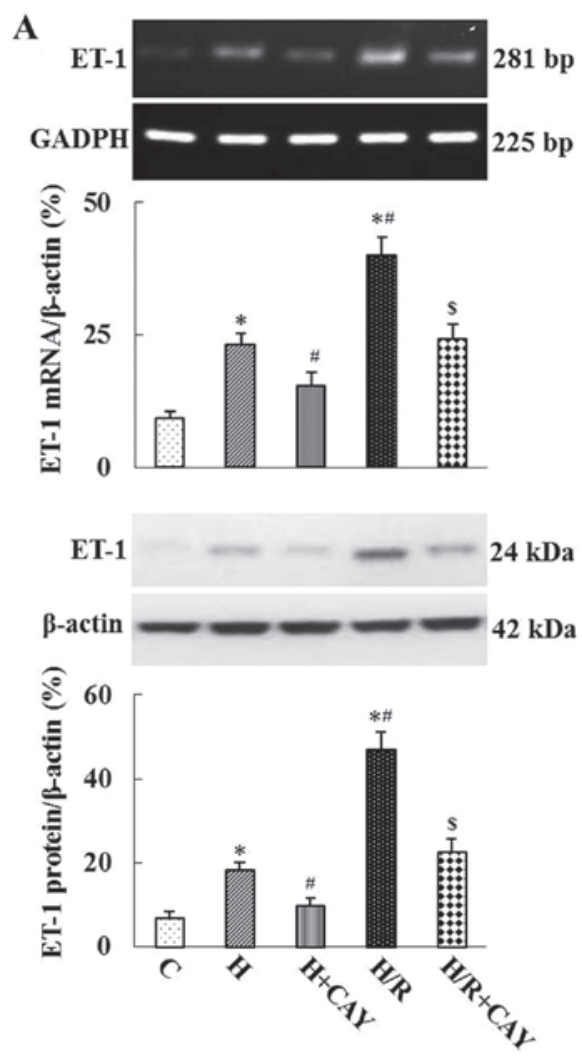
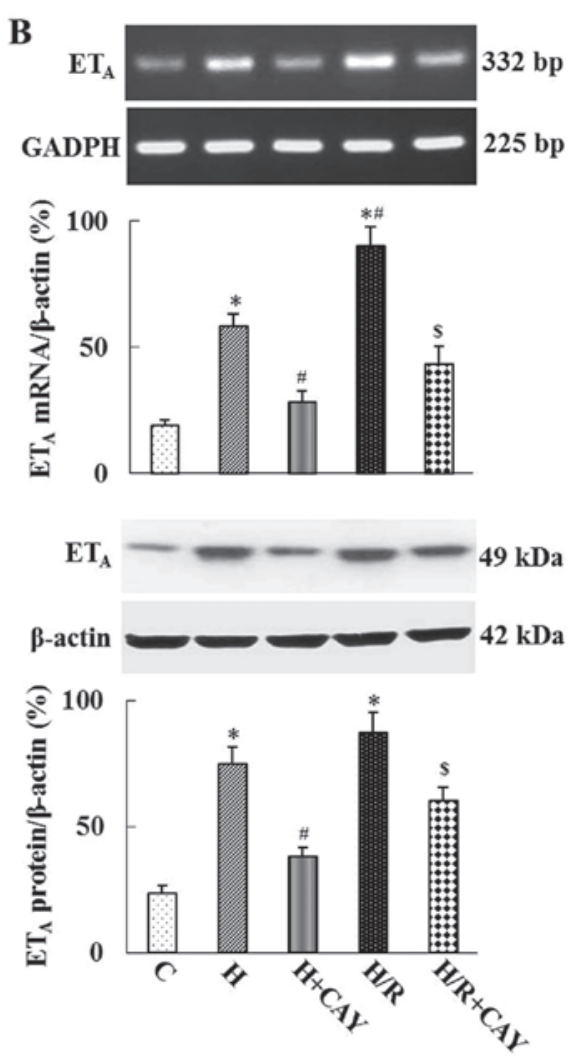

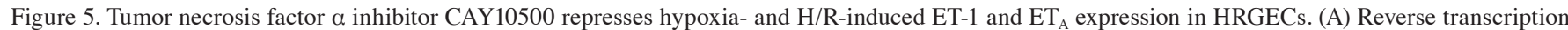

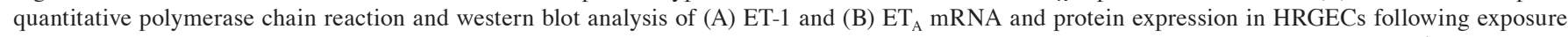
to: Hypoxia; hypoxia and CAY10500; H/R; and H/R and CAY10500. Values are presented as the mean \pm standard deviation ( $\mathrm{n}=4 / \mathrm{group}$ ). ${ }^{*} \mathrm{P}<0.05$ vs. C; ${ }^{\#} \mathrm{P}<0.05$ vs. H; ${ }^{\text {P }}<0.05$ vs. H/R. ET-1, endothelin 1; ETA, ET-1 receptor type A; HRGECs, human renal glomerular endothelial cells; C, control group; H, hypoxia only group; H/R, hypoxia/reperfusion group; CAY, CAY10500. 
was observed in ET-1 and $\mathrm{ET}_{\mathrm{A}}$ expression levels compared with those of the sham group $(\mathrm{P}<0.05)$. In addition, mRNA and protein expression levels of ET-1 and $\mathrm{ET}_{\mathrm{A}}$ in the I/R group were significantly increased compared to those in the ischemia only group $(\mathrm{P}<0.05$ or $\mathrm{P}<0.01)$.

$I / R$ increases TNF- $\alpha$ and IL- 6 mRNA and protein expression levels in mouse kidneys. As shown in Fig. 2, RT-qPCR and western blot analyses demonstrated that following I/R, mRNA and protein expression levels of the inflammatory cytokines TNF- $\alpha$ and IL- 6 were significantly increased compared to those in the sham and ischemia groups $(\mathrm{P}<0.05$ or $\mathrm{P}<0.01)$. However, ischemia alone also caused a moderate but significant increase in TNF- $\alpha$ and IL-6 expression levels compared with those of the sham group $(\mathrm{P}<0.05)$. These data were further confirmed using ELISA assays, which showed that TNF- $\alpha$ and IL- 6 protein expression levels in mouse plasma following ischemia and $I / R$ were significantly increased $(P<0.05$; data not shown).

Effect of hypoxia/reoxygenation on TNF- $\alpha$ and IL- 6 mRNA and protein expression in HRGECs. Hypoxia is a primary mediator of tissue damage following I/R (13). In kidneys, ET-1 is predominantly produced by glomerular endothelial cells (5). In the present study, HRGECs were subjected to hypoxia for $3 \mathrm{~h}$ followed by reoxygenation for $1 \mathrm{~h}$. As shown in Fig. 3, hypoxia alone as well as H/R significantly increased TNF- $\alpha$ and IL-6 mRNA and protein expression levels in HRGECs $(\mathrm{P}<0.05$ or $\mathrm{P}<0.01)$ in a comparable pattern to that of TNF- $\alpha$ and IL-6 expression in mouse kidneys following ischemia and $\mathrm{I} / \mathrm{R}$.

TNF- $\alpha$ increases ET-1 and $E T_{A} m R N A$ and protein expression in HRGECs. In order to elucidate the role of inflammation in ischemia- and hypoxia-induced ET-1 and $\mathrm{ET}_{\mathrm{A}}$ expression, HRGECs were treated with various concentrations of TNF- $\alpha$. As shown in Fig. 4, TNF- $\alpha$ increased the mRNA and protein expression of ET-1 and $\mathrm{ET}_{\mathrm{A}}$ in HRGECs in a dose-dependent manner. In addition, as shown in Fig. 5, hypoxia and H/R significantly increased the mRNA and protein expression levels of ET-1 and ET ${ }_{\mathrm{A}}$ in HRGECs compared with those in the control group. Furthermore, the TNF- $\alpha$ inhibitor CAY 10500 significantly inhibited hypoxia- and H/R-induced ET-1 and $\mathrm{ET}_{\mathrm{A}}$ expression $(\mathrm{P}<0.05$ or $\mathrm{P}<0.01$; Fig. 5).

\section{Discussion}

The results of the present study demonstrated that ET- 1 and its receptor $\mathrm{ET}_{\mathrm{A}}$ were significantly upregulated in mouse kidneys following ischemia and $\mathrm{I} / \mathrm{R}$; in addition, the expression of inflammatory cytokines TNF- $\alpha$ and IL- 6 was markedly increased in ischemic and I/R kidneys. Furthermore, mRNA

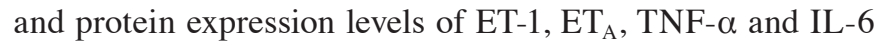
were markedly increased in HRGECs following exposure to hypoxia and $\mathrm{H} / \mathrm{R}$. These data indicated that inflammation may be involved in ischemia- and hypoxia-induced ET-1 and $\mathrm{ET}_{\mathrm{A}}$ expression in kidneys and renal endothelial cells. In order to further elucidate the role of inflammation in ischemia- and hypoxia-induced ET-1 and $\mathrm{ET}_{\mathrm{A}}$ expression, HRGECs were treated with TNF- $\alpha$; as expected, TNF- $\alpha$ increased mRNA and protein expression levels of ET-1 and $\mathrm{ET}_{\mathrm{A}}$ in HRGECs in a dose-dependent manner. Of note, following treatment with the TNF- $\alpha$ inhibitor CAY10500, the hypoxia- and H/R-induced increase in ET-1 and $\mathrm{ET}_{\mathrm{A}}$ expression was significantly attenuated in HRGECs. These results therefore suggested that ischemia and hypoxia may enhance the upregulation of ET-1 and $\mathrm{ET}_{\mathrm{A}}$, which is, at least in part, dependent on the production of inflammatory cytokines.

ET-1 is an amino acid peptide primarily produced by endothelial cells (4). In kidneys, ET-1 is produced by renal glomerular endothelial cells (5). ET-1 is a pro-inflammatory factor, which has an important role in maintaining normal renal functions (14). Upregulation of ET-1 and its receptors have also been reported to be involved in the development of acute and chronic renal diseases (6,7). Inflammation is a typical response and indicator of $\mathrm{I} / \mathrm{R}$ injury; in addition, inflammation results in the influx of inflammatory mediators, which are responsible for tissue injury in organs subjected to ischemia and/or $\mathrm{I} / \mathrm{R}(15,16)$. Inhibition of inflammatory responses has been demonstrated to attenuate I/R-induced tissue damage $(17,18)$. The results of the present study demonstrated that inflammatory mediators were involved in the expression of ET-1 and its receptor $\mathrm{ET}_{\mathrm{A}}$ in kidneys subjected to acute ischemia and/or I/R. Furthermore, these results also indicated that inflammation-mediated ET-1 and $\mathrm{ET}_{\mathrm{A}}$ expression in kidneys may, at least in part, be responsible for acute renal injury following $\mathrm{I} / \mathrm{R}$.

The present study further investigated the role of inflammation on ET-1 and $\mathrm{ET}_{\mathrm{A}}$ using an in vitro study on HRGECs, which were previously reported to produce ET-1 and express $\mathrm{ET}_{\mathrm{A}}$ receptor in kidneys $(5,19)$. The results of the present study revealed that the mRNA and protein expression levels of ET-1, $\mathrm{ET}_{\mathrm{A}}$, TNF- $\alpha$ and IL- 6 were markedly increased in HRGECs following $\mathrm{H} / \mathrm{R}$ or hypoxia alone. Hypoxia commonly occurs following tissue ischemia and results in tissue and organ damage due to oxygen deficiency. However, reoxygenation or reperfusion following hypoxia or ischemia may further increase tissue damage due to the increased production of reactive oxygen species (ROS) (20). The results of the present study also showed that inhibition of inflammation through treatment with a TNF- $\alpha$ inhibitor significantly repressed hypoxia-induced ET-1 and $\mathrm{ET}_{\mathrm{A}}$ expression in RGECs. This therefore confirmed an association between inflammation and ET-1/ET $\mathrm{A}_{\mathrm{A}}$ expression.

In conclusion, the results of the present study demonstrated that inflammatory responses were involved in ischemia and hypoxia-induced ET-1 and $\mathrm{ET}_{\mathrm{A}}$ expression in kidneys and HRGECs. In addition, the present study may provided evidence for a potential therapeutic target for the prevention of renal failure following ischemia/reperfusion.

\section{Acknowledgements}

The present study was supported by a grant from the National Natural Science Foundation of China (no. 31401246; Beijing, China).

\section{References}

1. Thurman JM: Triggers of inflammation after renal ischemia/reperfusion. Clin Immunol 123: 7-13, 2007. 
2. Kher A, Meldrum KK, Wang M, et al: Cellular and molecular mechanisms of sex differences in renal ischemia-reperfusion injury. Cardiovasc Res 67: 594-603, 2005.

3. Chen YT, Tsai TH, Yang CC, et al: Exenden-4 and sitagliptin protect kidney from ischemia-reperfusion injury through suppressing oxidative stress and inflammatory reaction. J Transl Med 11: 270, 2013.

4. Marasciulo FL, Montagnani M and Potenza MA: Endothelin-1: the yin and yang on vascular function. Curr Med Chem 13 1655-1665, 2006.

5. Vlachojannis JG, Tsakas S, Petropoulou C, et al: Endothelin-1 in the kidney and urine of patients with glomerular disease and proteinuria. Clin Nephrol 58: 337-343, 2002.

6. Vlachojannis J, Tsakas S, Petropoulou C and Kurz P: Increased renal excretion of endothelin-1 in nephrotic patients. Nephrol Dial Transplant 12: 470-473, 1997.

7. Chen HC, Guh JY, Chang JM, et al: Plasma and urinary endothelin-1 in focal segmental glomerulosclerosis. J Clin Lab Anal 15: 59-63, 2001

8. Tan RJ, Zhou L, Zhou D, et al: Endothelin receptor a blockade is an ineffective treatment for adriamycin nephropathy. PLoS One 8: e79963, 2013.

9. Ong AC, Newby LJ and Dashwood MR: Expression and cellular localisation of renal endothelin-1 and endothelin receptor subtypes in autosomal-dominant polycystic kidney disease. Nephron Exp Nephrol 93: e80, 2003.

10. Watson AM, Li J, Schumacher C, et al: The endothelin receptor antagonist avosentan ameliorates nephropathy and atherosclerosis in diabetic apolipoprotein E knockout mice. Diabetologia 53: 192-203, 2010.

11. Wihelm SM, Simonson MS, Robinson AV, et al: Endothelin up-regulation and localization following renal ischemia and reperfusion. Kidney Int 55: 1011-1018, 1999.
12. Abu-Salen N, Ovcharenko E, Awad H, et al: Involvement of the endothelin and nitric oxide systems in the pathogenesis of renal ischemic damage in an experimental diabetic model. Life Sci 91: 669-675, 2012

13. Adhami F, Liao G, Morozov YM, et al: Cerebral ischemia-hypoxia induces intravascular coagulation and autophagy. Am J Pathol 169: 566-583, 2006.

14. Richter CM: Role of endothelin in chronic renal failure-developments in renal involvement. Rheumatology (Oxford) 45 Suppl 3: iii36-iii38, 2006.

15. Daemen MA, van't Veer C, Denecker G, et al: inhibition of apoptosis induced by ischemia-reperfusion prevents inflammation. J Clin Invest 104: 541-549, 1999.

16. Lutz J, Thürmel K and Heemann U: Anti-inflammatory treatment strategies for ischemia/reperfusion injury in transplantation. J Inflamm (Lond) 7: 27, 2010.

17. Du X, He S, Jiang Y, et al: Adiponectin prevents islet ischemia-reperfusion injury through the $\mathrm{COX} 2-\mathrm{TNF} \alpha-\mathrm{NF}-\kappa \mathrm{B}$-dependent signal transduction pathway in mice. J Endocrinol 218: 75-84, 2013.

18. De Vries B, Matthijsen RA, Wolfs TG, et al: Inhibition of complement factor C5 protects against renal ischemia-reperfusion injury: inhibition of late apoptosis and inflammation. Transplantation 75: 375-382, 2003.

19. Wendel M, Knels L, Kummer W and Koch T: Distribution of endothelin receptor subtypes ETA and ETB in the rat kidney. J Histochem Cytochem 54: 1193-1203, 2006.

20. Leonard MO, Kieran NE, Howell K, et al: Reoxygenation-specific activation of the antioxidant transcription factor Nrf2 mediated cytoprotective gene expression in ischemia-reperfusion injury. FASEB J 20: 2624-2626, 2006. 